\title{
Narrar la villa entre el espectáculo y la experiencia: Cuando me muera quiero que me toquen cumbia, de Cristian Alarcón
}

\section{ขe Regina Cellino / Universidad Nacional de Rosario - CONICET / aretu_cellino@hotmail.com}

\section{Resumen}

Cristian Alarcón narra la villa, en Cuando me muero quiero que me toquen cumbia. Vidas de pibes chorros (2003), a partir del entramado de relatos de vidas individuales que se entrecruzan en torno a la muerte del Frente Vital, y a través de su experiencia en ese espacio marginal. Asimismo, el cronista no enumera los hechos ocurridos, contrariamente, reconstruye la muerte del «santo de los pibes chorros» en una trama en la que se mezcla la historia del fin de una época, la traición, desintegración familiar, engańos, enamoramiento, dolor, heroicidad, muerte, el secreto y el mito. Es decir, los condimentos propios del melodrama. De esta manera, Alarcón configura la versión otra —individualizada - de los documentos periodísticos y televisivos al inscribir y escribir las voces de los testigos a través de su propia experiencia dentro de la villa. Creemos que la decisión de elegir la crónica para narrar la historia se sustenta no sólo en la posibilidad de incorporar las voces de los protagonistas, sino también en poder relatar la experiencia del cronista en un espacio y tiempo ajeno al suyo.

Palabras clave: crónica $\cdot$ espectáculo $\cdot$ villa $\cdot$ melodrama - experiencia

\section{Abstract}

Cristian Alarcón, in his chronicle Cuando me muera quiero que me toquen cumbia. Vida de pibes chorros (2003), narrates the shantytowns, from individual stories of life that interconnect between each other around the death of the Frente Vital, through his personal experience along this slum. In that sense, the narrator doesn't enlist the facts that occurred, but he reconstructs the death of the "pibes chorros' Saints, in a story which is the combination of the end of an era, treason, family breakup, deceit, falling in love, pain, heroism, death, secret, and myth: all typical ingredients of melodrama. In this way, Alarcón creates an opposite version -a single one- from the ones that the press and television documentaries show. He achieves that by registering and writing the witnesses' voices. Following with this reasoning, the author creates a story about life and death in the shantytown, from a different perspective that the one that is shown by the mass media. We believe that the decision of choosing a chronicle to narrate the story is not only based on the chance of including the characters' voices, but also the possibility to include the narrator's personal experience in a foreign space and time.

Key words: chronicle $\cdot$ spectacle $\cdot$ shantytowns • melodrama $\cdot$ experience 